\title{
Evalds erindringer fra 1. Verdenskrig
}

Af PEDER ROSTGAARD EVALD

Som de fleste andre unge sønderjyske mænd blev Peder Rostgaard Evald indkaldt til tysk krigstjeneste under 1. Verdenskrig. Under Besættelsen holdt han et foredrag i Starup skole om sine oplevelser i Vestpreussen, det nuværende Polen, i de allerførste dage af 1 . Verdenskrig. Det er manuskriptet til dette foredrag, som er trykt med nutidig retskrivning i det følgende med forord om forfatteren fortalt af hans to døtre, Kirsten Rostgaard Petersen og Anna Rostgaard Rasmussen, i juli 2011. Artiklen er illustreret med postkort, som forfatteren sendte hjem under krigen. Billedteksterne er den hilsen, der står $\mathrm{p}$ den anden side af postkortene.

\section{Forord}

Peder Rostgaard Evald blev født på en gård i Bevtoft, dengang Nordslesvig, den 24. juni 1891 som nr. fem i en søskendeflok på seks. Han gik naturligvis i tysk skole, men talte sønderjysk derhjemme. De nærmeste år efter skolegangen ved vi ikke noget om, men, som han selv skriver, var han på Bornholms Højskole 1911-12, senere var han på Askov højskole i 2 halvår, hvor blandt andet Th. Arnfred prægede ham meget. I 1922 giftede han sig med en sønderjysk pige, Kirstine Margrethe Petersen fra Jernhyt, og sammen fik de tre piger: Kathrine, født 1924, gift med Niels Finderup Nielsen, som var søn af den lærer Nielsen, som indledningsvis er omtalt i krigserindringerne, Anna, født 1926, og Kirsten, født 1929.

Vi havde trods beskedne kår en dejlig barndom med forældre, der syntes, vi skulle bruge alle vore evner, så vi fik alle lov at gå på Haderslev Katedralskole, hvor vi to yngste tog studentereksamen i henholdsvis 1945 og 1948. Selv gik far og mor aldrig i stå, men var virksomme og medlevende $\mathrm{i}$ det nære samfund, til de var helt op i 80-årsalderen.

Krigsoplevelserne blev til på opfordring af førstelærer Jakob Finderup Nielsen, Starup skole ved Haderslev. Han bad far fortælle om sine oplevelser som marinesoldat i 1. Verdenskrig (1914-18), da alle sønderjyske unge mænd blev indkaldt til at deltage i krigen, meget 


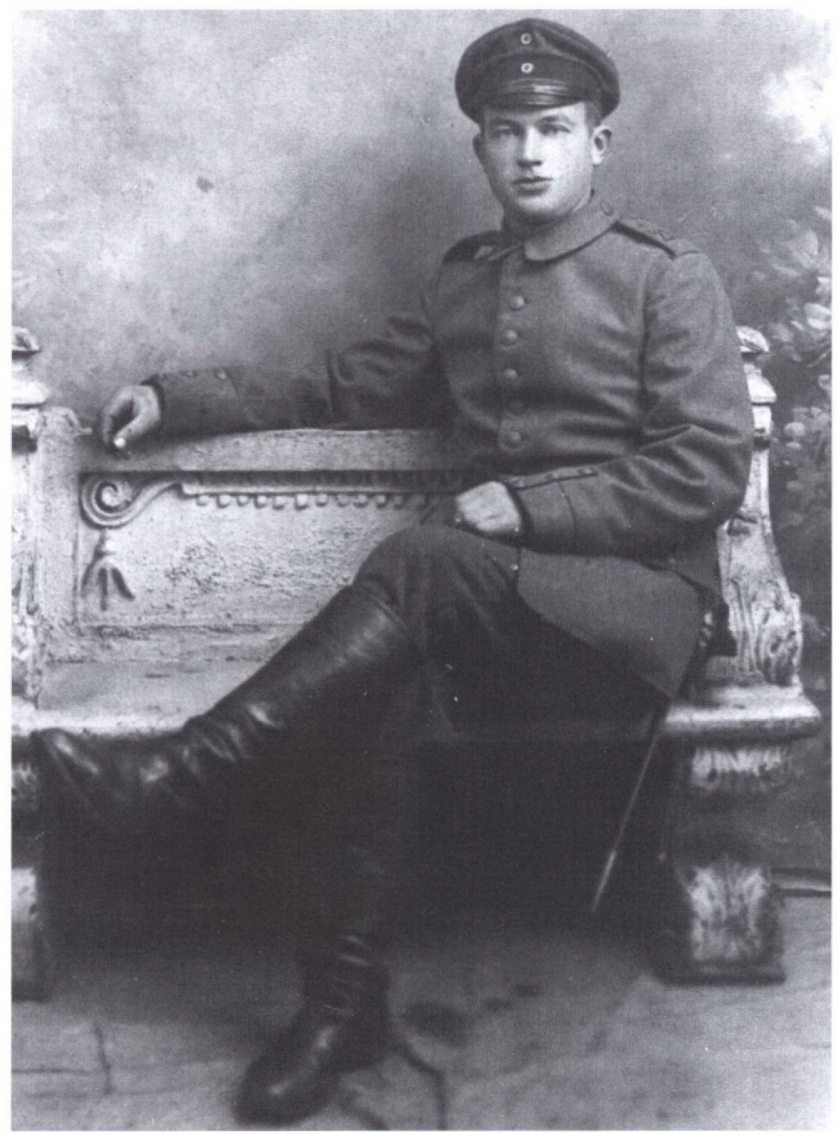

Fotografi af forfatteren i tysk uniform.

mod deres vilje, på tysk side. Foredraget blev holdt i Starup skole for et aftenskolehold i 1943 eller 1944.

Far fortalte egentlig ikke os børn så meget om krigen; men indimellem fortalte han os lidt om, hvordan det var at være barn i Bevtoft under tysk herredømme. F.eks. fortalte han, hvordan han og hans kammerater skulle hilse på de tyske, ridende gendarmer ved at tage huen af, når de red forbi, og hvordan de, når de rendte deres vej eller ikke hilste høfligt nok - fik en ordentlig overhaling! Han fortalte også om møder på kroen, hvor man sang forbudte danske sange (særlig yndet var: »Det haver så nyeligen regnet«), og om hvordan sådanne møder, hvis der var tyske embedsmænd i farvandet, pludselig for- 
andredes til uskyldige "landbrugsfaglige« møder; det syntes vi var spændende!

Hele fars tilværelse bar præg af hans stærke tilknytning til Danmark.

En af de helt store begivenheder $\mathrm{i}$ hans og mors liv blev derfor også, da »Nordslesvig « i 1920 ved Genforeningen blev til »Sønderjylland", takket være en kold afstemningsdag (den 10. februar), som senere blev fejret hvert år af D.S.K. (=Dansksindede Sønderjyske Krigsdeltagere) og af os derhjemme. Da Danmark den 9. april 1940 blev besat af tyskerne, var det et hărdt slag for os alle, men denne gang havde sønderjyderne skæbnefællesskab med hele Danmark, det var den store forskel.

Fars ungdomsår blev præget af først to år lang militærtjeneste og så de efterfølgende fire krigsår, alt sammen i tvungen tysk uniform. Disse ungdomsår, følte han, blev »stjålet« fra ham. Efter sine to år på Askov Højskole blev han uddannet elektriker og endelig legetøjsfabrikant (i beskedent format).

I sin sparsomme fritid læste han meget og gerne. Hans interesser var mange. De strakte sig fra astronomi og Brandes' taler til historie, nordisk mytologi og rejsebeskrivelser. Han læste op for os af »Tæj'lovnssjov«, muntre jyske historier, som vi husker den dag i dag. Interessen for at læse gav han videre til os piger, som han og mor, trods beskedne kår, gav chancen for at få den uddannelse, som de ikke selv fik. Vi mindes far som et retsindigt, videbegærligt og eftertænksomt menneske, som har forstået at få ting til at gro og skabe glæde og tryghed omkring sig, både $i$ hjemmet og blandt naboer og venner $i$ det nære samfund.

\section{Peder Rostgaard Evald fortæller}

I har vel nok hørt adskillige mennesker fortælle om oplevelser fra den sidste krig (1914-18), og det kunne for så vidt synes overflødigt, at jeg nu også fortæller jer lidt om mine oplevelser. Min hensigt var egentlig at fortælle jer lidt om Polens land og folk, men da mit kendskab hertil stammer fra krigsårene 14-18 er det jo næsten umuligt at fortælle noget, uden at krig og krigsbegivenheder kommer til at spille en betydelig rolle $\mathrm{i}$ det, man fortæller. Desuden har lærer Nielsen udtrykkeligt ønsket, at jeg også skulle fortælle krigsoplevelser, og jeg vil så begynde med dem. Det vil sige, at det egentlig snarere er for- 
spillet til mine krigsoplevelser, jeg vil fortælle om, og jeg har valgt dette afsnit, dels fordi det står mere levende for mig i dag end senere oplevelser, dels fordi jeg er temmelig sikker på, at det ikke ligner andre krigshistorier, som I har hørt.

Jeg tror, det er sådan, at de fleste krigsdeltagere, når de skal fortælle om deres oplevelser, som regel kun prøver på at fremstille de ydre omstændigheder, men fortier den egentlige oplevelse, nemlig det indtryk den har gjort på dem selv, og de tanker, som begivenhederne vækker til live. Det bliver på den måde kun skallerne og ikke kernen, som tilhørerne får del $\mathrm{i}$; dette forhold kan skyldes flere ting, men i de fleste tilfælde skyldes det vel nok en slags sjælelig blufærdighed, som gør sig gældende og måske også det, at man ikke ser sig i stand til at give sine tanker form og sammenhæng, sådan som man gerne ville. Desuden mangler jo for tilhørerne hele miljøet, alle de forhold, der betinger den indre oplevelse. Man fristes derfor til at vælge lette emner, hvortil ikke knyttes nogen særlig sjælelig oplevelse. Jeg vil da heller ikke gøre nogen undtagelse idet stykke, i alt fald ikke til at begynde med. Til slut skal jeg så prøve på at fortælle om en oplevelse, som jeg synes har betydet noget for mig.

Ved krigens udbrud i 1914 lå jeg som infanterist i fæstningen Thorn i provinsen Vestpreussen. Byen ligger ved Weichselfloden ikke langt fra den daværende russiske grænse. Man må jo huske på, at et selvstændigt land, som hed Polen, eksisterede ikke dengang; det havde ganske vist eksisteret før, men var blevet erobret og delt imellem de omliggende, store stater Rusland, Østrig og Tyskland, idet dog Rusland havde bemægtiget sig den centrale del af landet med hovedstaden Warschau eller Warszawa, som den hedder på polsk.

For ikke at skabe håbløs forvirring i min fortælling i aften vil jeg derfor blive nødt til at kalde den russisk besatte del af Polen for Rusland og den tysk besatte del for Tyskland. En stor del af provinsen Vestpreussen, byen Thorn indbefattet, var gammelt polsk område, men hørte altså nu under Tyskland ganske på samme måde som Sønderjylland dengang hørte under Tyskland. Thorn var en by på ca. 25-30.000 indbyggere, men med en meget stor garnison, der dels er fordelt $\mathrm{i}$ forterne rundt omkring byen. Et fort er en selvstændig, underjordisk forsvarsstilling. Byen var fra gammel tid omgivet af en meget solid ringmur, der dog ikke spillede nogen rolle i forsvarsmæssig henseende, men den kunne på sine steder se meget romantisk ud. Over Weichselfloden førte en kombineret færdsels- og jernbanebro ca. 


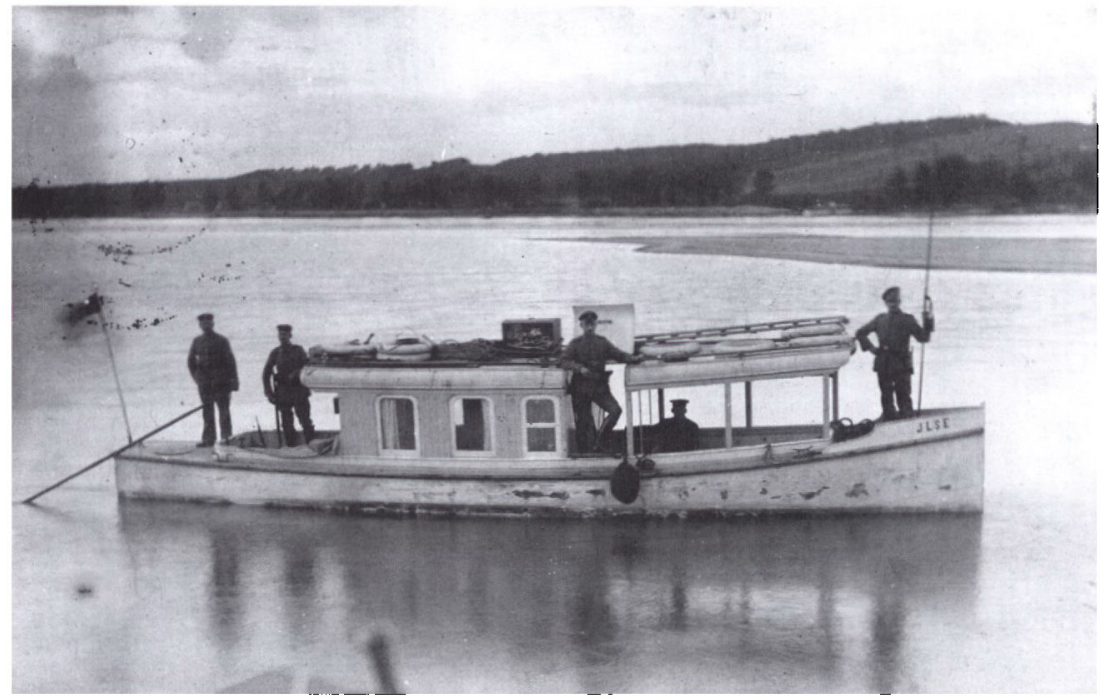

Wroclawek d. 9/10 14

Kære Forældre! Sender jer her, et billede af motorbåden "Ilse«, som jeg nu sejler med. Det er fotograferet her hvor vi nu ligger. Jeg häber, at I kan kende mig derpå. Jeg stär agter. Manden $i$ forstavnen har en erobret kosaklanse $i$ hånden og hans kasket på hovedet. Jeg har det ellers godt.

Mange karlige hilsner fra eders hengivne Peder.

en $\mathrm{km}$ lang (for øvrigt er Thorn kendt verden over som fødeby for en berømt videnskabsmand: Nicolaus Kopernikus (1473-1543)).

Allerede omkring 25. juli blev alle garnisonerne langs den russiske grænse mobiliserede. Vi fik vore gamle farvestrålende uniformer byttet med de nye feltgrå, fik skarpe patroner udleveret og bajonetterne slebet osv., og der udfoldede sig et liv og en travlhed $i$ byen som $i$ en myretue. Mange nye småkommandoer blev dannet, og deriblandt et patruljekommando på Weichselfloden. Det kommando, jeg tilhørte, skulle stille tre mand, og jeg blev den ene af dem. Kommandoet førte navnet "Weichselflotille« og bestod af en lille hvidmalet regeringsdamper, som hed »Ente«, og tre motorbåde. Hele kommandoet, der førtes af en løjtnant, bestod af 36 mand af næsten alle våbenarter. Fartøjerne, der til at begynde med havde civilt betjeningsmandskab, viste sig snart at være meget dårligt egnet til formålet, særlig fordi de gik for dybt i vandet. De tre af dem var tjenestebåde fra floder og kanaler inde i Tyskland, hvor farvandet er reguleret, så der altid er en nogenlunde dyb sejlrende. De var også gode nok, så længe vi holdt 


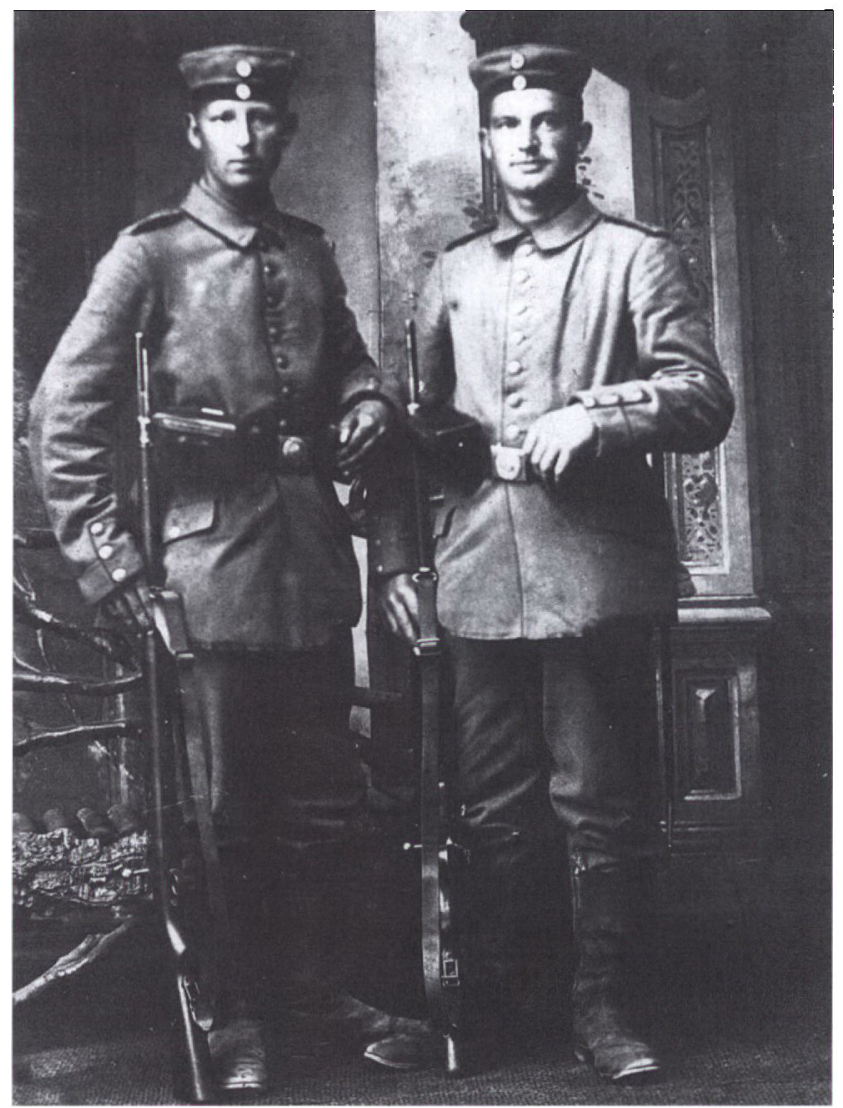

Onsdag d. 22/9 1914

Kære far og mor!

Jeg vil bare meddele jer, at jeg har det godt. Jeg har for en 8 dage siden modtaget dit brev fra 22/8, kare mor - og siger mange tak derfor. Ja, lad os stole på $G u d$, og når man tænker på ham, så er det slet ikke svært selv $i$ den vildeste kamptummel, så behøver man jo ikke at frygte deden og fjendens kugler.

I hảbet om et glad gensyn de bedste hilsner fra eders hengivne son Peder.

os inden for Tysklands grænser, men meningen var jo netop, at vi skulle sejle ind på russisk område, hvor floden ikke er reguleret, og tilmed på den årstid, hvor vandstanden er lavest. Godt var det altså ikke, men det skulle jo gå, og så gik det, som det kunne. Dette forhold var ganske vist skyld $i$, at over fem procent af den oprindelige besætning efter knap en måneds forløb satte livet til, men det er en historie for sig, som jeg ikke skal komme ind på i aften. 
Mine to kompagnikammerater og jeg kom om bord på damperen. Meningen med os infanterister var, at vi skulle sættes i land på dertil egnede steder af flodbredden og så gå patrulje ind $\mathrm{i}$ landet.

Fra Thorn var der kun ca. otte $\mathrm{km}$ med floden til den russiske grænse. Jeg antager, at det har været den 29. juli, at vi for første gang sejlede op ad floden til grænsen. Det viste sig snart, at russerne havde trukket sig tilbage fra grænsen i vort afsnit, og så kunne vi naturligvis ikke dy os for at sejle over grænsen, selvom der endnu ikke var erklæret krig. Der gik et par dage på den måde, uden at der hændte noget særligt. En gang imellem så vi russiske kavalleripatruljer på afstand, men uden at det kom til sammenstød. Da vi den 1. august hen imod aften var for hjemadgående efter en tur på en snes kilometer ind på russisk territorium, råbte en tysk toldembedsmand os an ved grænsen og fortalte, at Tyskland havde erklæret Rusland krig. Det forekom os lidt komisk, eftersom vi syntes, at vi allerede i flere dage havde været i krig med Rusland. Den dybe alvor i denne tidende var næppe nok nogen af os unge mennesker $i$ stand til at fatte. Vi forstod jo nok, at det kunne komme til at gælde livet for os selv, men vi kunne ikke fatte omfanget af al den elendighed, dette blev indledningen til.

Vi sejlede så til Thorn og tog kul ind for næste morgen på ny at tage ud på togt. Denne gang gik det op ad en lille biflod på russisk territorium til en lille by, som hed Czishoczineck. Bådene blev forankret, der blev sat vagtposter ud, og resten af besætningen drog i fuld krigsmaling med løjtnanten i spidsen op gennem byens gade (der var kun én) og svingede til sidst igennem en stor træport ind på en åben plads foran en meget pompøs bygning. Det viste sig at være et stort kurhotel. Terrassen foran huset var fuldt af mennesker, og et orkester spillede. Men jeg skal love for, at idyllen hurtigt blev afbrudt, så snart vi viste os, løjtnanten med revolver $i$ hånd og vi andre $i$ hælene på ham. Musikken standsede brat, som den var blevet hugget over, og alle kurgæsterne for op og forsvandt så hurtigt, som om selve den Onde var dukket op midt iblandt dem. Et øjeblik efter var der ikke et menneske at se. Et par patruljer blev sendt ud for at undersøge den nærmeste omegn, og et par vagter blev sat ud. Alle vi andre gik op på terrassen og satte os til rette. Nu skulle vi have varm mad, sagde løjtnanten. Det havde vi ikke fået i adskillige dage. Værten blev kaldt ud, og da flere af de tyske soldater talte polsk, voldte det ingen vanskeligheder at forklare ham, hvad vi ville. Vi fik så maden og betalte med en lap papir, som skulle kunne indløses med penge på kommandanturet i Thorn. 
$\mathrm{Nu}$ blev truppen delt i flere afdelinger. Det største hold, deriblandt jeg, blev sendt hen på et saltværk, som lå i nærheden. Jordbunden her var saltholdig, og vandet blev ved render ledet hen over høje risgærder. Renderne var utætte $\mathrm{i}$ bunden og vandet sivede ud over risgærderne og fordampede i solvarmen. Saltet blev så tilbage på risene. Det så pragtfuldt ud i solskinnet med de mange skinnende hvide risgærder, der så ud, som var de overpudret med sne.

En pram, som lå på floden ved saltværket halvvejs lastet med salt, blev beslaglagt og $\mathrm{i}$ løbet af eftermiddagen lastet færdig og bugseret ned til damperen for at tages på slæb.

Det var imidlertid blevet aften og temmelig mørkt af en augustaften at være, men alle patruljer var ikke vendt tilbage endnu. Så blev der sendt nye patruljer ud for at finde dem, forsynet med signalpistoler til at skyde farvede lyskugler op i luften med, og derved vejlede vore formentlig vildfarne kammerater. Det blev en ret eventyrlig færd i den stille sommernat. Fra damperen blev der med visse mellemrum skudt gule lyskugler til vejrs, for at vi kunne finde retning tilbage. Vi skød med grønne kugler, og ovre til venstre for os skød man med rødt. Vi sparede ikke på krudtet. For det første var det jo et ganske flot fyrværkeri med disse lyskugler, og for det andet længtes vi alle efter vor soveplads om bord, selvom det kun var en kold jernplade med et uldtæppe over os og tornystret som hovedpude. Mange tanker gik gennem mit hoved den aften, mens vi stavrede af sted i det fuldstændig ukendte terræn med sandsletter og krat og vandløb og atter sand. Den lune sommernat, lyssignalerne, hundenes tuden og gøen fra husene $\mathrm{i}$ byen, alt forekom mig så uvirkeligt og fantastisk.

Mest dog måske det, at jeg, den fredelige bondekarl fra den lille landsby i Sønderjylland, nu pludselig var ved at blive hvirvlet ind $\mathrm{i}$ verdensbegivenhedernes malstrøm. Og nu skulle til at gå på menneskejagt, fordi tyskerne havde gjort sig til herrer i mit hjemland.

Jeg tænkte på, hvordan det mon nu så ud derhjemme. Jeg vidste, at begge mine brødre nu øjeblikkelig ville blive indkaldt til krigstjeneste.

Endelig, noget over midnat, var vi igen samlet ved bådene, der blev kastet los, og langsomt, ganske langsomt, for ikke at løbe på grund gik det ned ad strømmen. Så endelig skulle vi få lov at sove, troede vi da, men vi måtte tro om igen.

En patruljefart i mørke, langt foran forpostlinjerne, er aldrig spændende. Man er både jæger og vildt på samme tid. Særlig spændende var det på en så lille flod som denne. Der kan lure farer overalt. Det 
er meget vanskeligt at manøvrere mellem sandbankerne, særlig når man sejler med strømmen. Der skal en gammel, øvet flodskipper til at gennemføre en sådan sejlads med held. Jeg havde dengang ikke megen forstand på flodsejlads, men jeg tager min hat af for den skipper, som den nat førte os velbeholdne ud på Weichsel. Ingen kan se, hvor der ligger store sten eller gamle træstammer, som kan ødelægge fartøjerne. Heller ikke kunne vi vide, hvilke farer der lurede inde på flodbredden, særlig hvor der var skovklædt, eller bag den næste omdrejning af floden. Lyssignalerne fra før kunne jo meget let have tilkaldt fjendtlige afdelinger, som nu kunne angribe os fra et baghold. I mørket, og uden plads til at manøvrere på, ville vi have været så godt som værgeløse. Desuden frembød vi jo altid et forholdsvist tydeligt mål på floden, mens vi ikke kunne se fjenden inde på bredden. Men heldigvis forløb hele turen fredeligt. Jeg kan ikke lade være at sammenligne en sådan tur med en opdagelsesrejse ind i et fuldstændigt ukendt land, som f.eks. Livingstones og Stanleys forste rejser i Afrika. Forholdene må i mange henseender, om ikke alle, have været de samme. Floderne har jo altid været indfaldsvejene i et ukendt land. Weichselfloden havde jo også for 1000 år siden været de nordiske vikingers indfaldsvej i Polen. Deres dragesnekker havde pløjet de samme bølger, som nu vore fartøjer. Og hvor meget var menneskeheden så gået frem i de 1000 år? Hvor stor var forskellen mellem før og nu? En forskel i teknik ganske vist, jo men var det stort mere! Ligesom de kom vi med ufred. Vort formål var ikke væsensforskelligt fra deres, og med hensyn til brutalitet tror jeg, at vi til tider kunne stå mål med dem. Vel er mangt og meget forandret på flodens bredder siden dengang, men floden er den samme. En ældgammel gubbe, der nu som for tusindvis af år siden støt går sin gang og øver sit værk og følger den lov, som engang er givet for den.

Nå, men for at komme tilbage til mit emne, vi kom jo da endelig ud på Weichsel og satte kursen nedad mod Thorn.

Hele eftermiddagen havde vi hørt en dump torden i nordøstlig retning. Ikke til at tage fejl af, det var artilleriild. Ved mørkets frembrud var det stilnet af, og vi havde allerede halvvejs glemt det. Da vi kom ud på Weichsel, så vi lyskasterne fra Thorn i virksomhed, og da vi var en tre-fire kilometer fra byen, mødte vi en anden damper, som gjorde vagttjeneste på floden. Den gav signal til at standse, og så fik vi forklaringen på skydningen. Kommandanturet $i$ Thorn havde fået melding om, at to fjendtlige kompagnier havde besat landsbyen Zlot- 
teri ved Drewensfloden tæt ved den russiske grænse, men på tysk område. Fæstningsartilleriet havde beskudt byen om eftermiddagen, og nu var der ordre til os om at undersøge sagen nærmere. Der var altså ikke andet at gøre end at forankre bådene igen. Drewensfloden var ikke dyb nok til, at vi kunne sejle derind. Den fremmede damper overtog vores første krigsbytte: prammen med salt. Vi blev kommanderet i land, sværmede ud i skyttekæde, og så gik det langsomt og så stille som muligt fremad imod landsbyen, mens lyskastere inde fra fæstningen belyste terrænet foran os. Jeg vil indrømme, at vi var noget spændte. Nu skulle det jo gå løs. Om et øjeblik ville vi stå over for en formodentlig stærk overlegen, fjendtlig styrke, og vi var ikke $i$ stand til at smutte væk i en fart, som vi kunne det med bådene på floden. Vi var snart tæt på byen og stadig ikke den mindste lyd fra den kant. Det var mystisk. Ikke engang hundegøen hørtes der. Vi måtte videre frem, ind imellem husene, ind på landsbygaden. Stadig ikke en sjæl at se eller høre. Byen var som uddød. Hist og her granathuller, og et par huse var brændt. Det var jo lutter træhuse, som hurtigt brændte ned. Vi blev i hast delt i flere grupper, som skulle undersøge husene. Der var heller ingen i husene. Min trup kom ind i værtshuset midt $i$ byen. En rev en tændstik. Det var skænkestue og tillige købmandsforretning, kunne man se. Over disken hang en række pølser ned fra loftet. Tændstikken gik ud, og det tog lidt tid, inden en ny blev tændt. Billedet var stadig det samme, undtagen pølserne. De var sporløst forsvundet. Vi var efterhånden blevet klar over, at byen var fuldstændig forladt af indbyggerne. Og samledes igen på gaden. Et sted havde man dog fundet et par gamle mennesker $i$ en kælder. Der havde ingen russere været $\mathrm{i}$ byen, men da beskydningen begyndte, var alle indbyggerne flygtet med undtagelse af disse to gamle, som ikke kunne.

Så kunne vi jo søge tilbage til vore både igen. Men løjtnanten var i meget dårligt humør. Han havde givet en af underofficererne ordre til at medtage signalpistoler på ekspeditionen. Om ordren var blevet misforstået eller glemt, ved jeg ikke, men der kom ingen signalpistoler med, og nu kunne man ikke give det aftalte signal ind til fæstningen. Løjtnanten svor på, at vi skulle ingen ro få foreløbig, og man kan ikke nægte, at han holdt ord. Så snart vi nåede bådene, blev »Anni«, den mindste og hurtigste, sendt af sted med melding om udfaldet af rekognosceringen. Løjtnanten ville straks op ad floden igen, men kaptajnen på damperen påstod, at vi manglede kul, og så måtte vi 


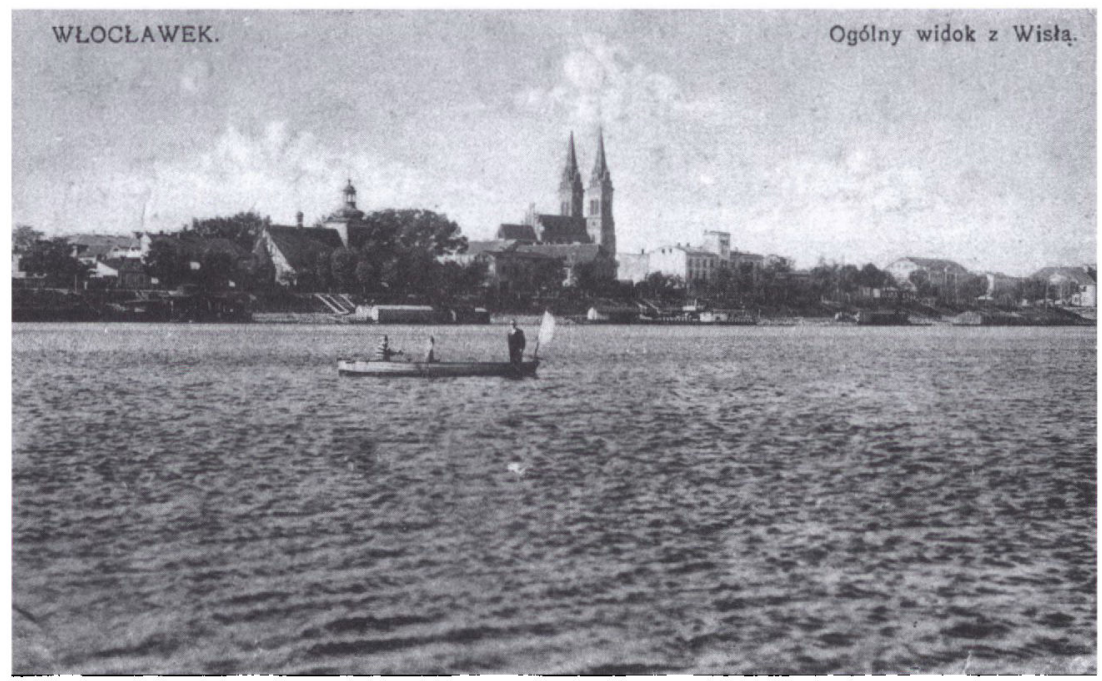

Kare far og mor!

Torsdag d. $18 / 814$

Jeg har $i$ dag igen lidt tid til at skrive. Vi har arbejdet hele natten og har nu formiddagen fri. Jeg har det stadig godt. Vi er nu stationeret her $i$ Wroclawek. Kjestine skrev, at Jorgen var i engelsk fangenskab lJorgen var Peders storebror og gift med Kjestine. Jargen tilbragte det meste af 1 . Verdenskrig $i$ den engelske fangelejr og kom ligesom Peder velbeholden hjem igenl. Jeg haber og tror at det ikke er sả slemt der, $i$ hvert fald ikke som $i$ det russiske. Jeg tror altid pa, at Vorherre forer os til det bedste.

$\mathrm{Nu}$ en hjertelig hilsen fra eders hengione Peder.

alligevel ind til Thorn. Da vi lidt uden for byen passerede et af forterne, blev vi pludselig beskudt af infanterister på fortet, selvom vi tydeligt nok førte det tyske flag. Vi søgte selvfølgelig dækning, så godt vi kunne, men der var ikke meget at dække sig bag. Damperen var til dette formål den mest umulige, man kunne tænke sig. Alligevel skete der ingen større skade, beskydningen varede et par minutter, og jeg nævner det kun for at illustrere den nervøsitet, som havde grebet de fleste i disse første krigsdage.

Vi fik taget vores kul ind, og så gik det igen op ad floden. Under farten plejede vi, foruden de almindelige vagtposter, at have en mand i forstavnen på hvert fartøj, som skulle holde udkig efter miner. Russerne kunne jo lade dem drive med strømmen ned imod os. Det var store, runde kugler, som flød lige i vandoverfladen. I fuldstændigt stille vejr kunne de slet ikke ses, men så snart det blæste lidt, blev de af og til synlige i den krusede vandoverflade. Den morgen blev vi 
klar over, at chefen stadig var i dårligt humør, for der blev sat dobbelte vagter og mineposter. Nå, men dagen gik uden særlige oplevelser. $\mathrm{Vi}$ ankrede op for natten ud for en lille købstad ca. 20-25 km inde i Rusland. Vi ankrede altid op midt i floden for en sikkerheds skyld, men nogen sikkerhed var der ganske vist ikke ved det heller. Med de par mand, vi var, ville vi kunne overrumples i mørket $i$ en håndevending. Nå, foreløbig gik det jo da godt. Jeg havde vagt den nat fra tolv til to. Engang hørte jeg hestetrampen på byens gader, og en bil hørtes også. Jeg gik så ned $\mathrm{i}$ kahytten og meldte sagen til løjtnanten. Han sov naturligvis og modtog min melding højst unådigt. Jeg skulle ikke vække ham for enhver småting. Han brugte ganske vist et kraftigere udtryk, men det var $\mathrm{i}$ hvert fald meningen, og så vendte han sig om på den anden side. Nå, der skete da heller ikke mere. Om morgenen hørte vi, at der havde været en trop russisk militær for at hente rekrutter. Om morgenen fik vi så våben osv. Det var det sædvanlige optog, løjtnanten i spidsen, og vi andre i halen på ham. På tilbagevejen hændte der pludselig noget: en beruset mand kom ravende ud fra en kælderbeværtning og stilede med udbredte arme lige imod løjtnanten, som han øjensynlig ville omfavne. Det må her indskydes, at det er skik og brug der $\mathrm{i}$ landet, at man byder sine venner velkommen med et favntag. Hvad manden sagde, husker jeg ikke, men han talte tysk, og man forstod, at han var glad over, at hans landsmænd nu kom til landet. Løjtnanten råbte »holdt« så højt, som det sig hør og bør for en tysk officer, men da manden ikke standsede, skød han ham ned med to revolverskud, og så spadserede vi videre og lod polakkerne om at tage sig af manden, der, som vi senere hørte, var død.

Vi gik så om bord og sejlede videre op ad floden til en større by Wtoclaweck, som ligger ca. $40 \mathrm{~km}$ fra grænsen. Vi stødte ikke på militær undervejs, men her ved byen lå en hel række floddampere og pramme. Her var altså noget for os at beslaglægge, og tilmed overraskede vi på én af damperne to russiske officerer, som blev taget til fange. Det blev en hel eskadre, som næste dags morgen lagde til ved kajen i Thorn. Seks erobrede dampere og nogle fuldtlastede pramme, og så medbragte vi oven i købet de to første krigsfanger, som blev taget under den krig. Det kunne jo ikke blive til mindre end rosende omtale i dagsbefalingerne for hele vort armekorps. Massefremstillingen af jernkors var ikke begyndt endnu, ellers havde vi jo nok fået en slat af dem i tilgift. 
Det var lige vand på løjtnantens mølle. Nu fik vi da endelig lidt fritid, og vi var ikke længe om at komme op i byen og få et solidt måltid varm mad. Joseph Ribazci's spisekælder kendte vi alle. Der fik man et godt måltid for 30 penning. Det kunne da ikke være billigere (i danske penge var det dengang ca. 25 øre). Joseph Ribazci - Joseph lyder jo jødisk, men Ribazci er afgjort polsk (på dansk ville manden hedde Fisker). Men prøv at skælde manden ud for jøde eller polak, det gør du i alt fald ikke mere end én gang. Nej, manden er tysker, endda med et meget militært tilsnit. Rank holdning, kraftigt Schnurbart osv., med andre ord: gammel militær. Det kniber med at få plads i lokalet, der er stopfuldt af soldater, som hele byen er det i disse dage. Der spises og drikkes øl i lange baner. Jo mere øl der drikkes, des sikrere er man på, at det kun er et øjebliks sag at slå Tysklands fjender. Inden jul er vi hjemme igen. Tyskland bliver så stærkt, så stærkt, og Rusland og England bliver så små, at man knap kan øjne dem. Ja, kunne man have klaret det med at drikke øl, havde krigen været vundet den aften.

Næste morgen er vi igen parat til at sejle op ad floden. Klokken fem bliver vi purret ud. Så ned ad landgangen og et stykke hen, hvor man bekvemt kan komme til at vaske sig ved flodbredden. Men hvad er nu det? Der ligger fuldt af fisk langs hele flodbredden, mest småfisk. Nogle er døde, resten halvdøde, det er meget mystisk. Der bliver ingen morgenvask denne gang. Vi farer hen på damperen og beretter om fænomenet. Øjeblikkelig bliver der sendt beretning om foreteelsen til kommandanturet, og inden en time er det bekendtgjort over hele byen, at vandet er forgiftet af russerne. Ingen må bruge vandet, hverken til vask eller andet.

Nå, men sejle $\mathrm{i}$ vandet måtte vi da, og vi sejlede så gådens opklaring i møde. Da vi kom på den russiske side af grænsen, lagde vi mærke til, at folk som sædvanlig både vaskede og hentede vand til husholdningsbrug. Ja, nu bagefter er jeg endda ikke sikker på, at de ikke forsynede sig særlig rigeligt med vand den dag. Vandet kunne altså ikke være forgiftet, og alligevel var der også her fuldt af døde og halvdøde småfisk. Endelig, da vi nåede Wtoclaweck, blev gåden opklaret. Aftenen forud havde der været et militært kommando i byen for at ødelægge de ting, tyskerne evt. kunne have brug for. Blandt andet havde de på en stor spritfabrik åbnet for indholdet af to vældige spritbeholdere og ladet det løbe ud i Weichsel. Det må unægtelig have været stærke sager, eftersom Thorn lå ca. $50 \mathrm{~km}$ derfra, og 


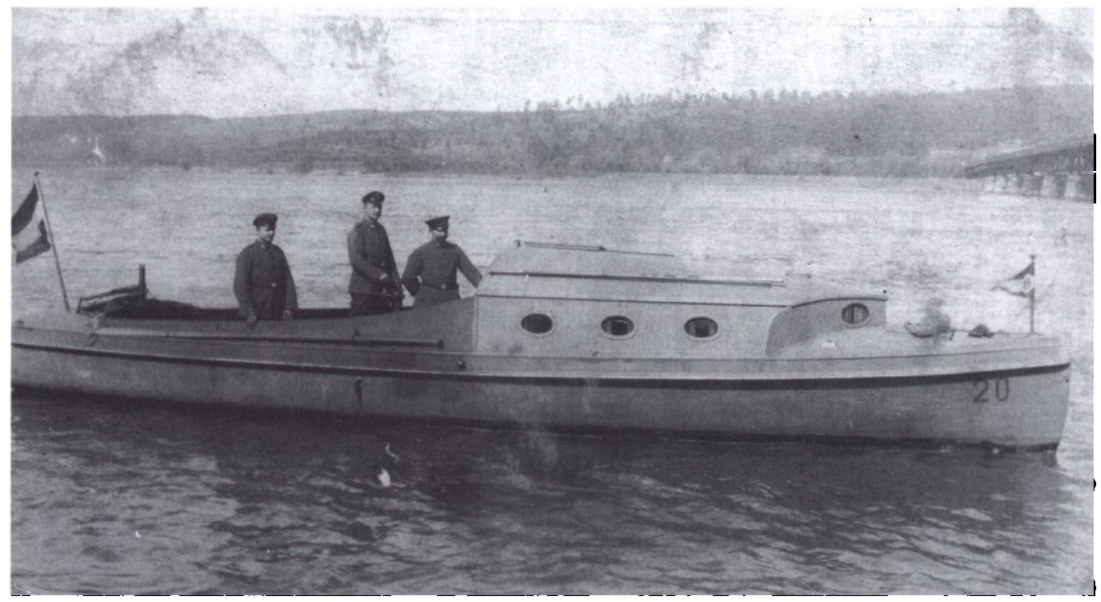

$3 / 416$

Kære Kjestine

Jeg rejser på torsdag over til Warszawa. Hvor jeg senere kommer hen, ved jeg endnu ikke. Min adresse er altså igen "Weichelflotille Warschau«. Jeg har det ellers stadig godt og håber, at det også er tilfældet med jer derhjemme. Hils far og mor og var selv hiertelig hilset.

Peder

en flod på en lille km's bredde er dog en ganske antagelig slat vand at blande med. En af mine kammerater påstod i den anledning, at krig var det mest meningsløse af alt. Her havde han sejlet rundt $i$ en kæmpemæssig toddy hele dagen uden så meget som at smage på den. Det kunne da aldrig have passeret ham i fredstid.

Dette røverliv på floden fortsatte nu i en ti-tolv dage omtrent på samme måde. En for mandskabet meget kærkommen afveksling var det dog, da vor berømmelige damper »Ente« en skønne dag løb på en sten og fik et stort hul i bunden, så den foreløbig var ubrugelig. Som dens afløser fik vi så en gammel fragtdamper, som hed »Fortuna«. Den var langt bedre egnet til formålet. Det var en hjuldamper, som kun gik 70-80 cm dybt, men det bedste ved den var, at her var plads til mandskabet $\mathrm{i}$ det store lastrum, og her kunne skaffes plads til en kabys, hvor der kunne koges mad til hele besætningen. På "Ente« havde vi måttet opholde os på dækket hele døgnet rundt. Skibets indre var optaget af den meget store chefskahyt, maskinrummet og et lille snævert folkelukaf, der lige kunne rumme skibets civile besætning. Desuden blev "Fortuna « forsynet med en solid skansebe- 
klædning udfyldt med sand og forsynet med skydeskår foroven, så nu havde vi nogen dækning i tilfælde af angreb.

Vi var efterhånden blevet mere og mere forvovne, for ikke at sige frække. Et par gange havde vi været i Plock, en større by ca. $80 \mathrm{~km}$ inde $i$ Rusland og lige så langt foran vore egne forposter, der stod ved grænsen. Af den russiske garnison i Plock var godt et halvt hundrede mand blevet tilbage, men når de så os komme op ad floden, tog de flugten (formodentlig har de troet, at vi var langt talrigere, end vi var), og lod os gå frit $\mathrm{i}$ land $\mathrm{i}$ byen. Ja, byens brandvæsen måtte endog køre nogle af os fire $\mathrm{km}$ ud ad vejen til Warschau, hvor vi sprængte en bro. Våben og andet blev beslaglagt, og en gammel tysker, som sad i fængslet, blev befriet og taget med. Han så for resten meget skummel ud, men hvad han havde forbrudt, ved jeg ikke, og hvor han senere blev af heller ikke. Nå, tredje gang vi ville til Plock, nåede vi kun halvvejs, så blev vi for første gang angrebet af russerne, og hermed var det forbi med vores »spillen herre " på floden. Vi måtte stadig trække os længere tilbage, indtil vi den 27 . august led et så afgjort nederlag, at kun meget få af os slap derfra med livet. $O g$ så begyndte forst den egentlige krig.

Til slut en lille oplevelse, som først i det fjerde krigsår fik en sandhed til at gå op for mig, eller i hvert fald til at stå klart for mig; den nemlig, at man aldrig skal adlyde andre blindt, men at man til enhver tid er ansvarlig for sin egen samvittighed.

Jeg var i 1917-18 stationeret $i$ en lille landsby ved floden Jegszczuna, en biflod til Bolz, som er biflod til Narev, som igen er den største biflod til Weichsel. Jeg var stationens leder, og mandskabet bestod af en syv-otte mand. Vi var nu langt bag ved fronten, og vor opgave var at virke som flodpoliti. Dertil hørte at kontrollere al færdsel på og ved floden, der ikke måtte overskrides uden legitimation. Hensigten hermed var at forhindre spioner, flygtede krigsfanger, smuglere osv. i at nå fra Tyskland til Rusland eller omvendt, idet man nu betragtede det erobrede område som hørende til Tyskland. Egnen var sumpet og ret utilgængelig, uden landeveje, som biler kunne færdes på, og floden, som egentlig kun var en stor å, kunne ikke besejles af de almindelige motorbådstyper. Vi blev derfor meget lidt kontrolleret af vore overordnede, og følgelig benyttede vi hovedsagelig tiden til jagt og fiskeri. Alle fiskefartøjer i vort distrikt var samlet ved en station, og ingen fisker måtte færdes på floden uden militær ledsagelse. For at opnå denne ledsagelse må fiskeren som regel aflevere halvdelen af 
fangsten til os. Jeg vil ikke påstå, at denne fordeling var retfærdig, eftersom fiskeren jo var fagmanden og desuden måtte lægge både båd og redskaber til, men nogen assistance havde han jo da som regel også af den soldat, som var med. Jeg for mit vedkommende blev meget interesseret $\mathrm{i}$ fiskeri og var meget ofte på fisketur. En dag efter en sådan tur et godt stykke ned ad floden blev fiskeren og jeg enige om at fortsætte på samme måde den næste dag, og for at spare arbejdet med at stage båden op imod strømmen til stationen, skjulte vi båden på flodbredden og gik til fods tilbage. Det begyndte at skumre, og vi gik og sludrede på polsk, som jeg med tiden havde fået lært en del af. På hjemvejen skulle vi passere tæt forbi en række birketræer, som længere borte endte $i$ et krat. Ved udkanten af trærækken stod en mand, som åbenbart ventede på os. Det var en smuk, stille sommeraften, og manden har jo kunnet høre vore stemmer i temmelig stor afstand. Men der stod et par buske mellem os og manden, så vi kunne ikke se hinanden rigtig tydeligt til at begynde med. Først da vi havde passeret buskene, blev jeg rigtig opmærksom på manden, og han har sikkert også først nu set, at jeg gik med et gevær i rem over skulderen og deraf sluttet, at han måtte have en tysk soldat for sig. Han tog et par sidelæns spring ind imod træerne og satte af sted langs med rækken. Jeg havde imidlertid, som det sad mig som gammel soldat $\mathrm{i}$ blodet, fået revet geværet fra skulderen og gjorde skudklar og råbte mit »Halt!«, idet jeg dog straks var klar over, at det var en undvegen russisk krigsfange, jeg havde for mig. Min instruks lød selvfølgelig på at skyde manden ned, så snart han ikke standsede ved tilråb. Alligevel skød jeg et skræmmeskud over hovedet på ham, men uden virkning, jeg skød endnu et skræmmeskud, men med samme resultat. Manden bare løb i ret linje bort fra mig, og hans brede ryg med den hvide proviantpose frembød for mig det bedst mulige mål at skyde efter. Hvad jeg i det øjeblik tænkte, ved jeg ikke. Måske tænkte jeg slet ikke, adlød blot mekanisk min instruks. Jeg tog sigte midt på den brede ryg med den hvide pose og trykkede af. Og så skete det mærkelige. Jeg vidste, at jeg havde fem patroner i bøssen, men der lød intet skud, bare et lille klik. Patronen var af en eller anden grund ikke gået af, noget som jeg i min seksårige tjenestetid ikke har oplevet hverken før eller siden, og som mangen soldat aldrig har oplevet. Det kan jo, trods sin sjældenhed, skyldes en meget naturlig og tilfældig ting. Men omstændighederne gør, at jeg netop ikke kan få mig selv til at tro på tilfældigheden. Jeg ved ikke, om jeg sagde: 


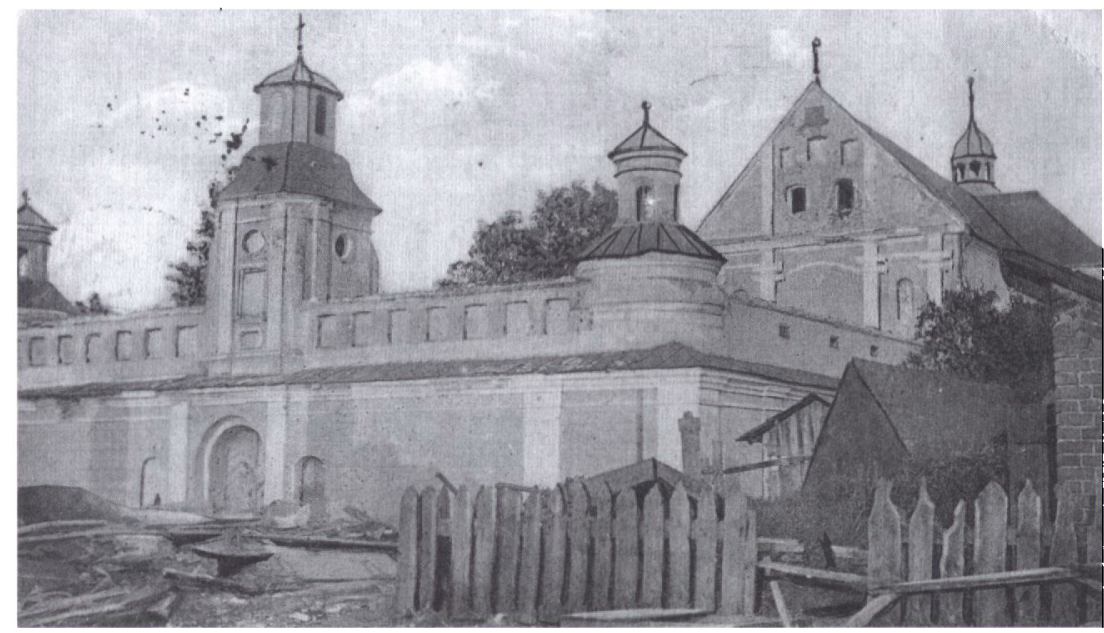

$19 / 1216$

En rigtig gladelig jul, kære far og mor. Det blev altså ikke denne gang endnu, at vi fik lov til at fejre jul derhjemme. Rigtig mange tak for de mange pakker med hønsekød, smor osv.

Mange hilsner fra eders Peder

"gud ske lov«, da jeg tog geværet fra skulderen, men jeg mente det i hvert fald. Jeg var øjeblikkelig klar over, at jeg havde været $\mathrm{i}$ begreb med at begå et drab for ikke at sige et mord. Én ting er at skyde på en modstander, der står over for én med våben i hånd, en anden at skyde en våbenløs mand ned bagfra, bare fordi han prøver at komme ud af elendigheden og vinde sin frihed. Hvis jeg havde gjort det, er jeg sikker på, at jeg ville have angret det resten af mit liv. Det blev jeg nu forskånet for. En russisk digter siger om en mand $i$ en lignende situation: "Dette blev hans straffedom, fordi han stred med fremmed vilje og samvittighed«. Det var jo netop dette, jeg havde gjort. Jeg havde i det afgørende øjeblik ikke lyttet til min egen samvittighed, men ladet mine foresattes bud træde $\mathrm{i}$ stedet for, altså ladet deres samvittighed være afgørende for mine handlinger. Det er det, jeg forstår ved blind lydighed. Det er blandt andet også det, som mange mennesker gør under den nuværende krig, og som engang, når rusen er forbi, vil hævne sig bittert på dem selv. Men ikke blot i krig, også i det daglige liv, og ikke mindst i vor tid gælder det: Lad aldrig andres samvittighed og vilje være afgørende for dine handlinger. Brug din egen! Du 
har fået den for det samme. Og måske nok den største gave, du har fået, en af de ting, der adskiller mennesket fra dyret.

$\mathrm{Nu}$ vil jeg ikke dermed sige, at det er den eneste gang, jeg har gjort mig skyldig i den forseelse, det er det langtfra. Men det var ved den lejlighed, jeg opdagede hvori fejlen bestod. Når vi kalder os kristne mennesker, kan der jo kun være én, som vi skylder absolut lydighed. Vi kan nok være lydige imod andre mennesker, bevares vel! Men kun med det forbehold, at vi ikke støder an imod Guds lov.

$\mathrm{Nu}$ er der måske nogen af jer unge mennesker, der synes, at det må da egentlig være spændende at være med i krig og opleve en hel del, særlig når det ikke går værre end i min fortælling $\mathrm{i}$ aften. Lad mig dertil sige, at det som regel går værre. Og lad mig også gøre opmærksom på, at der i en krig ikke blot er en fare for den legemlige sundhed, men også for den sjælelige sundhed, særlig for ganske unge mennesker. I den forbindelse kunne jeg have lyst til at fortælle om en lille samtale, jeg havde med en mand kort efter krigen.

Jeg var, kort efter min hjemkomst i 1919, en lille tur på Bornholm og besøgte højskolen derovre, som jeg havde været på i 1911-12. Højskoleforstanderen præsenterede mig for en pastor Møller, som var en meget kendt missionspræst derovre, og fortalte, at jeg havde været med i krigen. »Har De virkelig været med hele tiden?«, sagde pastor Møller.« Det må da have været forfærdeligt««« Åh, jeg er jo sluppet godt fra det«, sagde jeg. »Er De nu også det? », sagde han, og så blev jeg tavs, det spørgsmål kunne jeg alligevel ikke svare på lige med det samme. Men jeg fik en vis respekt for pastor Møller, at han sådan lige straks kunne stille mig det spørgsmål, som jeg burde have stillet mig selv for længe siden.

\section{Zusammenfassung}

Wie die meisten anderen Männer aus Sønderjylland, wurde Peder Rostgaard Evald im 1. Weltkrieg für den deutschen Kriegsdienst einberufen. Während der deutschen Besatzung 1940-45 hielt er in der Schule in Starup einen Vortrag über seine Erlebnisse der allerersten Kriegstage des 1 . Weltkriegs in Westpreußen, dem heutigen Polen. Das hier wiedergegebene Manuskript des Vortrages wurde von seinen Töchtern Kirsten Rostgaard Pedersen und Anna Rostgaard Rasmussen im Juli 2011 mit einem Vorwort versehen. 